\title{
Mansagar Lakejaipur, Rajasthan Biodiversity: Issues and Challenges
}

\author{
Dr. Neetu Mahawar \\ Assistant Professor, Department of Environmental Science, Kanoria PG Mahila Mahavidiyalaya, Jaipur
}

\begin{abstract}
Inland waters and freshwater biodiversity constitute a valuable natural resource, in economic, cultural, aesthetic, scientific and educational terms. Their conservation and management are critical to the interests of all humans, nations and governments. Yet this precious heritage is in crisis. Fresh waters are experiencing declines in biodiversity far greater than those in the most affected terrestrial ecosystems, and if trends in human demands for water remain unaltered and species losses continue
\end{abstract}

Keywords: lake Pollution, species, BOD

\section{Introduction}

Lake are ecologically an important to maintaining the microclimate and fulfilling direct and indirect uses like provide water for domestic, industrial and agricultureuse ground water recharge and fishing etc.in spite of their fundamental importance to Huma being, fresh water lakes have been severely affected by a multitude of anthropogenic disturbances which have pose serious negative effect on the structure and function of the ecosystem.

This paper reported ecological status with special reference to avian fauna at mansagar lake, Jaipur Rajasthan.We document threats to global freshwater biodiversity under five headings: water pollution; Sedimentation; Eutrophication; water scarcity and invasion by exotic species.

\section{Study Area}

Mansagar Lake popularly known as Jal Mahal. It is the only significant water body in Jaipur city. It is statue between $26^{\circ}$ $57^{\prime} 12.50^{\prime \prime} \mathrm{N} \& 75^{\circ} 50^{\prime} 46.04^{\prime \prime}$ E. Its a artificial lake it was created by construction of a dam across the Darbhawati River between Khilagarh hills and Nahargarh Hills.Lake catchment area is $23.5 \mathrm{~km}^{2}$. Maximum depth is 4.5 M(15feet).

Lake provide habitats for various migratory and resident birds. Mansagar lake is the habitat of more the 180 species birds. The bird commonly sighted included some endangered, uncommon, vulnerable, threatened and near to threatened species.

\section{Birds Study}

Birds were sited in and around the wetland area during the winter session in the year 2013

\begin{tabular}{|c|c|c|}
\hline Scientific name & $:$ & Aythyaferina \\
\hline Common name & $:$ & common pochard \\
\hline Family & $:$ & Anatidae \\
\hline occurrence & $:$ & Migratory \\
\hline Conservation Status & $:$ & Vulnerable \\
\hline
\end{tabular}

\begin{tabular}{|c|c|c|}
\hline Scientific name & $:$ & Mycterialeucocephala \\
\hline Common name & $:$ & painted stork \\
\hline Family & $:$ & Ciconiidae \\
\hline occurrence & $:$ & Native \\
\hline Conservation Status & $:$ & Near to threatened \\
\hline
\end{tabular}

\begin{tabular}{|c|c|c|}
\hline Scientific name & $:$ & Platalealeucorodia \\
\hline Common name & $:$ & Common spoon bill \\
\hline Family & $:$ & Threskiornithidae \\
\hline occurrence & $:$ & Migratory \\
\hline
\end{tabular}

\begin{tabular}{|l|l|l|}
\hline Scientific name & $:$ & Padionhaliaetus \\
\hline Common name & $:$ & Osprey \\
\hline Family & $:$ & Pandionidae \\
\hline occurrence & $:$ & Migratory \\
\hline
\end{tabular}

\begin{tabular}{|l|l|l|}
\hline Scientific name & $:$ & Fulicaamericana \\
\hline Common name & $:$ & American coot \\
\hline Family & $:$ & Rallidae \\
\hline occurrence & $:$ & Migratory \\
\hline Scientific name & $:$ & Anasclypeata \\
\hline Common name & $:$ & northern shoveler \\
\hline Family & $:$ & Anatidae \\
\hline occurrence & $:$ & Migratory \\
\hline
\end{tabular}

\begin{tabular}{|l|l|l|}
\hline Scientific name & $:$ & Anasacuta \\
\hline Common name & $:$ & pintail \\
\hline Family & $:$ & Anatidae \\
\hline occurrence & $:$ & Migratory \\
\hline
\end{tabular}

\begin{tabular}{|l|l|l|}
\hline Scientific name & $:$ & Tringastagnatilis \\
\hline Common name & $:$ & marsh sandpiper \\
\hline Family & $:$ & Scolopacidae \\
\hline occurrence & $:$ & Migratory \\
\hline
\end{tabular}

\begin{tabular}{|l|l|l|}
\hline Scientific name & $:$ & Phalacrocoraxfuscicollis \\
\hline Common name & $:$ & Indian Cormorant \\
\hline Family & $:$ & cormorant \\
\hline occurrence & $:$ & Native \\
\hline
\end{tabular}

\begin{tabular}{|l|l|l|}
\hline Scientific name & $:$ & Phalacrocoraxfuscicollis \\
\hline Common name & $:$ & Indian pond heron \\
\hline Family & $:$ & Ardeidae \\
\hline occurrence & $:$ & Native \\
\hline
\end{tabular}




\section{International Journal of Science and Research (IJSR)}

ISSN (Online): 2319-7064

Index Copernicus Value (2015): 78.96 | Impact Factor (2015): 6.391

\begin{tabular}{|l|l|l|}
\hline Scientific name & $:$ & Phalacrocoraxfuscicollis \\
\hline Common name & $:$ & Indian pond heron \\
\hline Family & $:$ & Ardeidae \\
\hline occurrence & $:$ & Native \\
\hline
\end{tabular}

\begin{tabular}{|l|l|l|}
\hline Scientific name & $:$ & Ardea alba \\
\hline Common name & $:$ & great egret \\
\hline Family & $:$ & Ardeidae \\
\hline occurrence & $:$ & Partially migratory \\
\hline
\end{tabular}

\section{Lake Water Quality Monitoring}
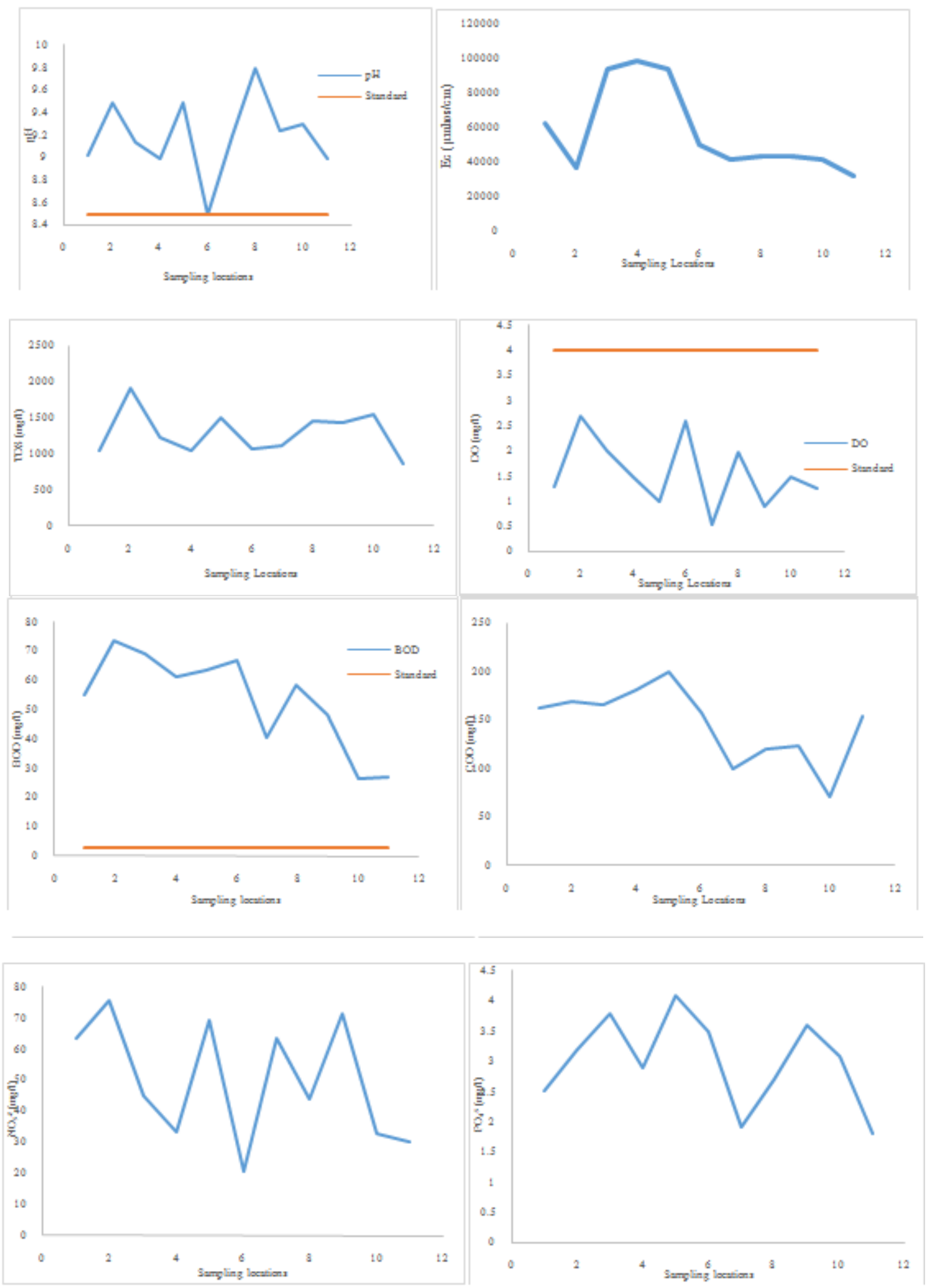

Volume 6 Issue 7, July 2017
Physic-chemical Characteristics

Water quality monitoring has been maintained at 9 sampling sits. The lake water samples were collected from the different samples were collected from different sited of study area in plastic bottles. Physical-chemical analysis of water was carried out for estimation of $\mathrm{pH}$, Total Dissolved Solids, Total Hardness, Calcium Hardness, Magnesium Hardness, DO, BOD, COD, Total Alkalinity, Chloride and fluoride ion concentration. Method suggested by APHA, AWWA, WPCF (2005) was employed. 
International Journal of Science and Research (IJSR)

ISSN (Online): 2319-7064

Index Copernicus Value (2015): 78.96 | Impact Factor (2015): 6.391

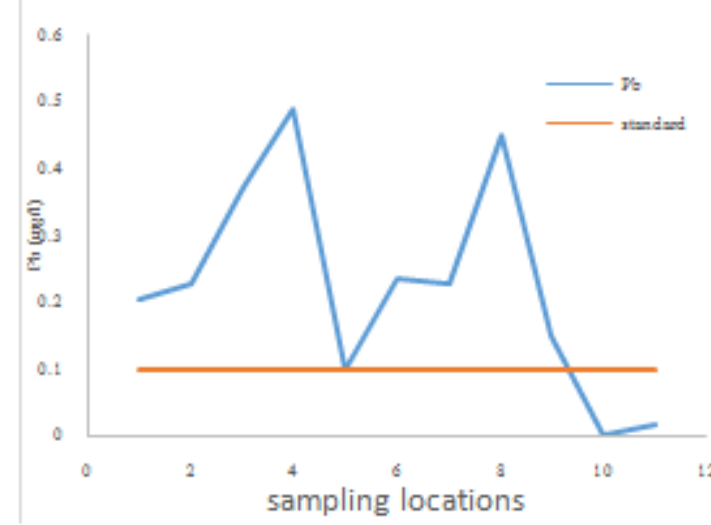

\section{Results and Discussions}

Lake is found highly polluted due to an untreated discharge of sewage and industrial and domestic effluent discharge into the lake.The water is Alkaline the maximum $\mathrm{pH}$ is 10.02. The BOD ranges 24.42 to $59.5 \mathrm{mg} / \mathrm{l}$ and COD ranges 60- $250 \mathrm{mg} / \mathrm{l}$ which denoted a very high amount of organic matter presence. DO found very low ranges zero to $2 \mathrm{mg} / \mathrm{l}$. which cause stress on aquatic organisms and even cause death. Toxic chemicals from industrial effluents cause death of fishes. Lake water was found to be green in colour due to floating green algae on the surface of water body.Green colour experience large algal bloom because of high level of nutrients ranges between 11.44 to $71.85 \mathrm{mg} / \mathrm{l}$ Nitrate and 3.6 to $0.4 \mathrm{mg} / \mathrm{l}$ phosphate. Toxic chemicals from industrial effluents cause death of fishes. The lake suffering from serious problem of siltation and Sedimentation.Decrees in surface area due to artificial land formation approximately 200 tons /year of plastics has been removed from the lake.

\section{Invasion of Exotic Species}

Introduce the Mangur (cat) fish in the Mansagar lake cause ecological damage.It is an African species about 0.5 feet long.It is banned in India this fish devours other small fishes and even birds.In the absence of predator it multiplies immensely thus posing a problem for resident species of birds.Reduction in small fishes cause food scarcity which directly influence migratory birds number and species diversity. During summer Lake facing water scarcity due to use of lake water in irrigation.

\section{Conclusion}

Sewage water is the most important source of lake water, their combined and interacting influences have resulted in population declines and range reduction of freshwater biodiversity.

\section{References}

[1] Kattan and Franco (2004): Bird diversity along elevational gradients in the Andes of Columbia: area and mass effects. Global Ecology and Biogeography Vol. 13pp 451-458.

[2] Shah Mustafa, Ulfat Jan G. and RaashidWaniMohammad (2013): Study on Distribution of Avian Fauna of Dachigam National Park, Kashmir,

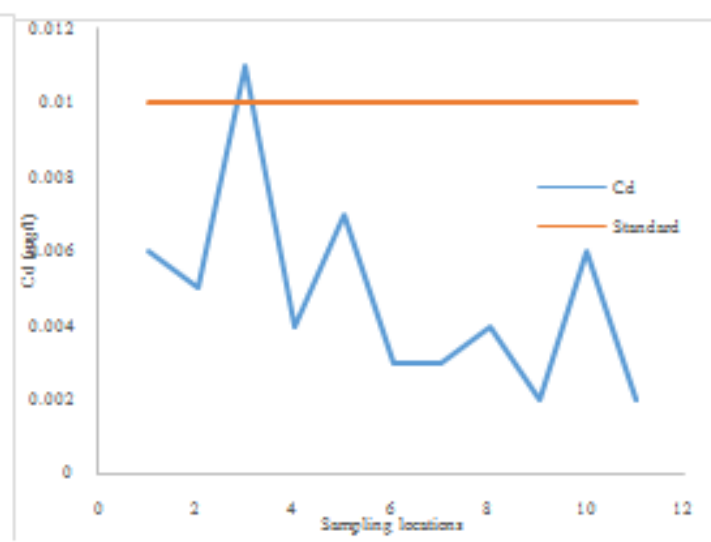

India. International Journal of Current Research, Vol. 5, Issue, 02, pp 266-270

[3] DesalgnAgarnesh and Subramanian C. (2015) studies on avian diversity in angereb forest and adjacent farm land with reference to rainy and post rainy seasons, north western Ethiopia. International Journal of Pure and Applied Zoology Volume 3, Issue 3, pp 219-225.

[4] John H. R. Gee,Barbara D. Smith,Katherine M. Lee, and SiânWyn Griffiths (1997): The ecological basis of freshwater pond management for biodiversity, Aquatic Conservation: Marine and Freshwater Ecosystems VOL.7,pp 91-104

[5] Saibal K. De and Cherylann Lobo(2000): lake restoration toward creating tourism infrastructure, proceedings of lake.

[6] David Dudgeon, Angela H. ArthingtonMark O. Gessner and Zen-Ichiro Kawabata (2006): Freshwater biodiversity: importance, threats, occurence and conservation challenges, Cambridge Journals Volume 81, Issue 2 pp. 163-182.

[7] David L. Strayer and David Dudgeon (2010): Freshwater biodiversity conservation: recent progress and future challenges, Journal of the North American BenthologicalSociety vol. 29(1) pp 344-358.

[8] Palmer, M., J. D. Allan, J. Meyer, and E. S. Bernhardt. (2007):River restoration in the twenty-first century: data and experiential knowledge to inform future efforts. Restoration Ecology Vol.15 pp 472-481.

[9] Palmer, M. A., A. P. Covich, B. Finlay, J. Gibert, K. D. Hyde, R. K. Johnson, T. Kairesalo, P. S. Lake, C. R. Lovell, R. J. Naiman, C. Ricci, F. F. Sabater, and D. L. Strayer. (1997):Biodiversity and ecosystem function in freshwater sediments.Ambio Vol.26 pp 571-577.

[10]Zedler, J. B. and S. Kercher. (2005):Wetland resources: occurence, trends, ecosystem services, and restorability. Annual Review of Environment and Resources Vol. 30 pp 39-74.

[11] Sharma K.P., Sharma Subhashaini, Sharma Shweta, Sharma P.P., Swami R.C.Singh P.K., and Rather G.S. (2007): Mansage lake : Past, Present and Future. Proceedings of Taal 2007 The $12^{\text {th }}$ World lake Conference pp 1530-1541. 